\title{
РАДIOTЕХНІКА ТА ТЕЛЕКОМУНІКАЦІї
}

УДК 004.62

DOI https://doi.org/10.32838/2663-5941/2020.1-1/06

\section{Борисов Г.О.}

Національний технічний університет України

«Київський політехнічний інститут імені Ігоря Сікорського»

\section{Гумен Т.Ф.}

Національний технічний університет України

«Київський політехнічний інститут імені Ігоря Сікорського»

\section{Трапезон К.О.}

Національний технічний університет України

«Київський політехнічний інститут імені Ігоря Сікорського»

\section{ДОСЛІДЖЕННЯ ПРОГРАМНИХ ОСОБЛИВОСТЕЙ ОБ'ЄДНАННЯ ANDROID THINGS HА ОСНОВI КОНЦЕПЦIÏ ІНТЕРНЕТУ РЕЧЕЙ}

Розглянуто програмні особливості платформи зі створення додатків Android Things. Визначено особливості підключення до платформи та проаналізовано режим передавання даних між платформою на основі «хмарних» сервісів і апаратною платою Аrdиіпо, яка забезпечує підключення та взаємодію датчиків у межах концепиї Інтернету речей. Наведено основні особливості з налаштування однієї з обраних «хмарних» платформ Інтернету речей - Samsung Artik Cloud. Зазначено, щзо платформа на апаратному (модуль захисту даних) і програмному рівнях дає змогу з боку користувача створити профіль для моніторингу даних, які знімаються з датчиків системи Інтернету речей. Отримано, що для використання «хмарної» платформи в Інтернеті речей достатньо виконати лише два програмних кроки - конфігураиіл Іо-проєкту в платформі і додавання пристрою (датчика) в межах підключення до цієё платформи.

Проведено детальний опис із налаштування «хмарної» платформи для окремого датчика, який у приміщенні вимірює температуру повітря. За цим описом створено алгоритм забезпечення зв 'язку масиву даних із датчика до «хмарного» середовища платформи. Наприклад, для пересилання даних з Android-додатка необхідно сформувати запит за кодом. Додатково зазначено, щзо для реалізаиії сервісів інтеграиії з IoT, наприклад для створення голосових повідомлень із набраного тексту, необхідно підключити до ІоТ додаткову платформу Тетьоо. Ця платформа через відповідне програмне забезпечення дає змогу додатково підключатись до операторів мобільного зв 'язку з паралельним конвертуванням текстових повідомлень у голосові. Особливістю иъього додатка слід назвати обмеження, яке полягає в тому, що довжина слів у повідомленні не повинна перевищувати межу у 12 текстових знаків. Це пояснюється тим, що у разі перевищення иієї межі речове повідомлення буде зі зникаючими голосовими звуками, щяо безпосередньо впливає на розбірливість мови.

Ключові слова: платформа, сервіс, датчик, профіль, илюз, архітектура.

Постановка проблеми. Стрімкий розвиток телекомунікаційних технологій призвів за останні роки до ситуації, коли вже будь-які побутові пристрої в помешканні людей володіють ознакою так званої «розумності», тобто характеризуються можливістю контролю через різні мобільні гаджети, які підключено до мережі Інтернет. Вже не $\epsilon$ новиною контроль і поливання рослин у кімнаті дистанційно через смартфон, контроль за віддаленою квартирою 3 підтримкою інфрачервоних датчиків і камер відеонагяду тоді, коли господар цієї квартири перебуває у відпустці. I навіть отримання інформації про погоду за вікном на моніторі комп'ютера через відповідний додаток програми Android Things стає дуже простою буденною справою. 3 іншого боку, збільшення кількості параметрів пристроїв для контролю повинно за теорією впливати на складність системи, до якої підключені ці пристрої. I основне завдання при цьому полягає у розробленні алгоритму, який зміг 
би впорядкувати певні параметри пристроїв, і це впорядкування повинно бути прозорим і простим. Це завдання стає основним, особливо, коли необхідно спроєктувати «розумний» будинок. Зрозуміло, що різні параметри будинку - показники лічильника електроенергії, витрати води, температура приміщення - повинні бути під рукою в господаря в режимі моніторингу в будь-який час. I цей моніторинг не повинен бути прив'язаний до відповідних лічильників чи датчиків у певному місці будинку.

Для зберігання даних моніторингу їхньої обробки та візуалізації, а також для надання різних сервісів для управління пристроями, які підключені до Інтернету є різні «хмарні» платформи. Вибір цієї платформи, iї налаштування, зміна параметрів і є одним 3 основних завдань у концепції Інтернету речей. Сама ж проблема полягає в тому, що обрана платформа повинна бути гнучкою як в управлінні, так і до змін під час додавання нових параметрів пристроїв. Крім того, всі дані, які передаються до платформи, повинні бути доступними i зручними для аналізу з боку користувача системи чи контролюючих органів, що надають житловокомунальні послуги.

Постановка завдання. Android Things [1] - це платформа для створення додатків на основі концепції Інтернету речей i популярних апаратних платформ, таких як Arduino Raspberry Pi 3. Образи програмного забезпечення створюються і доставляються на пристрої через програмне налаштування Android Things Console [2]. Android Things надає безліч інструментів для створення ІоТ-додатків i управління даними. Натомість правильне налаштування «хмарного» середовища як ємності для зберігання даних від кінцевих пристроїв системи $\epsilon$ основним завданням, особливо, коли ця платформа використовується для збирання, аналізу та візуалізації різнорідних фізичних параметрів, аудіовізуальної інформації від датчиків, камер, сенсорів у режимі реального часу.

Метою статті є визначення програмних особливостей із налаштування платформи Samsung Artik Cloud, що є ключовою ланкою під час створення інформаційної системи на основі концепції Інтернету речей. Додатково необхідно знайти алгоритм або послідовність керівних команд, який визначає процедуру формування та отримування запиту про миттєве значення фізичного параметру, що $€$ об'єктом вимірювання датчика, який входить до складу системи на основі IoT.

Виклад основного матеріалу дослідження. Як правило, всі параметри 3 приладів, які підключені до системи на основі концепції Інтернету речей, отримуються через показники різних сенсорів системи та обробляються локально. Але зазвичай додатки для Інтернету речей посилають ці дані в так звану інформаційну «хмару». Через це «хмарні» платформи Інтернету речей сьогодні відіграють дуже важливу роль.

Як тільки інформаційні дані стають доступними на рівні «хмари» Інтернету речей [3], з'являється можливість на рівні підключення до цієї платформи проведення комплексного аналізу, де потрібна велика обчислювальна потужність. Тут використовують зазвичай такі технології, як машинне навчання, штучний інтелект $\mathrm{i}$ аналіз великих даних.

\section{Сервіси хмарної платформи.}

Звичайна платформа Інтернету речей надає такий набір сервісів: сервіс з'єднання / підключення, сервіс зберігання даних, сервіс обробки подій, управління пристроями, візуалізація даних, інтеграція сервісів.

Ядром сервісу підключення є з'єднання і передавання даних між платформою ІоТ і віддаленої платою [4]. Платформи підтримують різні протоколи для спрощення процесу підключення: Rest API i HTTP, MQTT, CoAP, тощо. Інакше кажучи, платформи надають набір програмних інтерфейсів, які можуть бути використані віддаленими платами i ІоТ для підключення та обміну даними. Крім того, вони надають набір SDK для різних плат, щоб зробити процес підключення швидким і простішим.

Сервіс зберігання даних служить для зберігання даних у «хмарі». Ці дані $є$ основою для інших сервісів.

Ці перші два види сервісу надаються майже всіма наявними «хмарними» платформами IoT, тоді як сервіс обробки подій є більш складним. Такий сервіс заснований на правилах і використовує збережені дані та події для запуску дій, які могли б мати вплив на плати ІоТ. Зазвичай всі події та дії конфігуруються через вебінтерфейс.

Сервіс управління пристроями бере на себе управління всіма пристроями системи ІоТ, підключеними до платформи. Іншими словами, це централізована адміністративна консоль для віддалених пристроїв. Візуалізація даних - це сервіс, що надається деякими «хмарними» платформами ІоТ для створення так званих інструментальних панелей (dashboards) із метою графічної візуалізації отриманих даних за допомогою гістограм / графіків.

Сервіс інтеграції корисний, коли ми хочемо інтегрувати якісь зовнішні сервіси типу повідомлень по електронній пошті, повідомлень у «Твіттері», тощо, і запускати ці сервіси відповідно до 
заздалегідь сконфігурованої події. На ринку $є$ кілька хмарних платформ IоT, наприклад: Google loT cloud, Microsoft Azure IoT, Amazon AWS IoT, Samsung Artik Cloud, Temboo, Ubidots.

Архітектура IоT речей зазвичай така:

1) рівень сенсорів;

2) плати Інтернету речей, шлюзи або комутатори;

3) «хмарні» платформи Інтернету речей;

4) високорівневі сервіси $з$ призначеним для користувача інтерфейсом для кінцевого користувача.

Іноді 3-й і 4-й пункти архітектури ІоТ можуть бути змінені місцями.

Особливості налаштування «хмарної» платформи.

Для того, щоб використати «хмарну платформу» IoT, потрібно виконати два кроки: конфігуруція проєкту Інтернету речей у «хмарній» платформі 3 наданням усієї інформації, включно з типом даних, і створення клієнта «хмарної» платформи Інтернету речей (Android Things-додаток), який обробляє підключення і посилає дані.

Хмарні платформи налаштовуватися приблизно однаково, і наведемо в статті приклад налаштування взаємодії «хмарної» платформи з ІоТ на прикладі SamsungArtik Cloud.

Це професійна платформа, яка надає майже всі згадані вище сервіси. Вона проста у використанні і надає кілька SDK, які спрощують процес обміну даними. В статті наведемо алгоритм налаштування обміну даними між Android Things-платою i «хмарою» Samsung Artik, використовуючи його Rest API-механізм (рис. 1).

\section{ÄRTIK"Cloud}

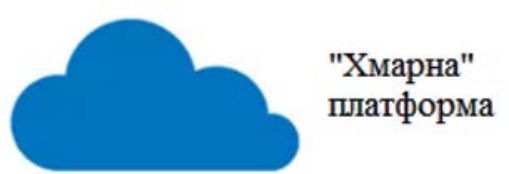

Датчики системи
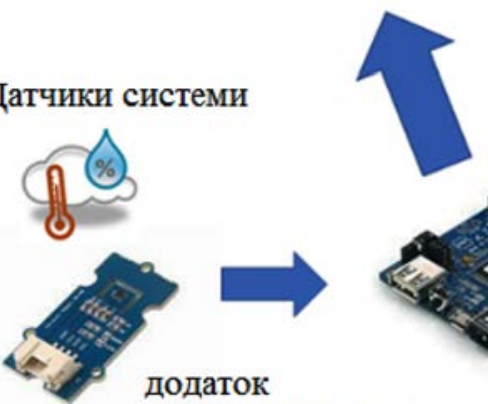

Android Things

\section{Рис. 1. Алгоритм частини архітектури IоT}

Налаштування «хмарної» платформи можна провести за таким алгоритмом:

1. Створити профіль у додатку платформи Samsung Artik Cloud. Після реєстрації відбувається налаштування профілю. В Samsung Artik Cloud у вікні розробника необхідно натиснути на кнопку Create device type і заповнити необхідні поля (рис. 2). Далі слід натиснути на кнопку Set up now, щоб налаштувати профіль для розроблення. У наступному вікні обрати, який проєкт буде груповим (Теат) або індивідуальним (Individual) project, а потім потрібно ввести необхідну інформацію. Після цього можна буде

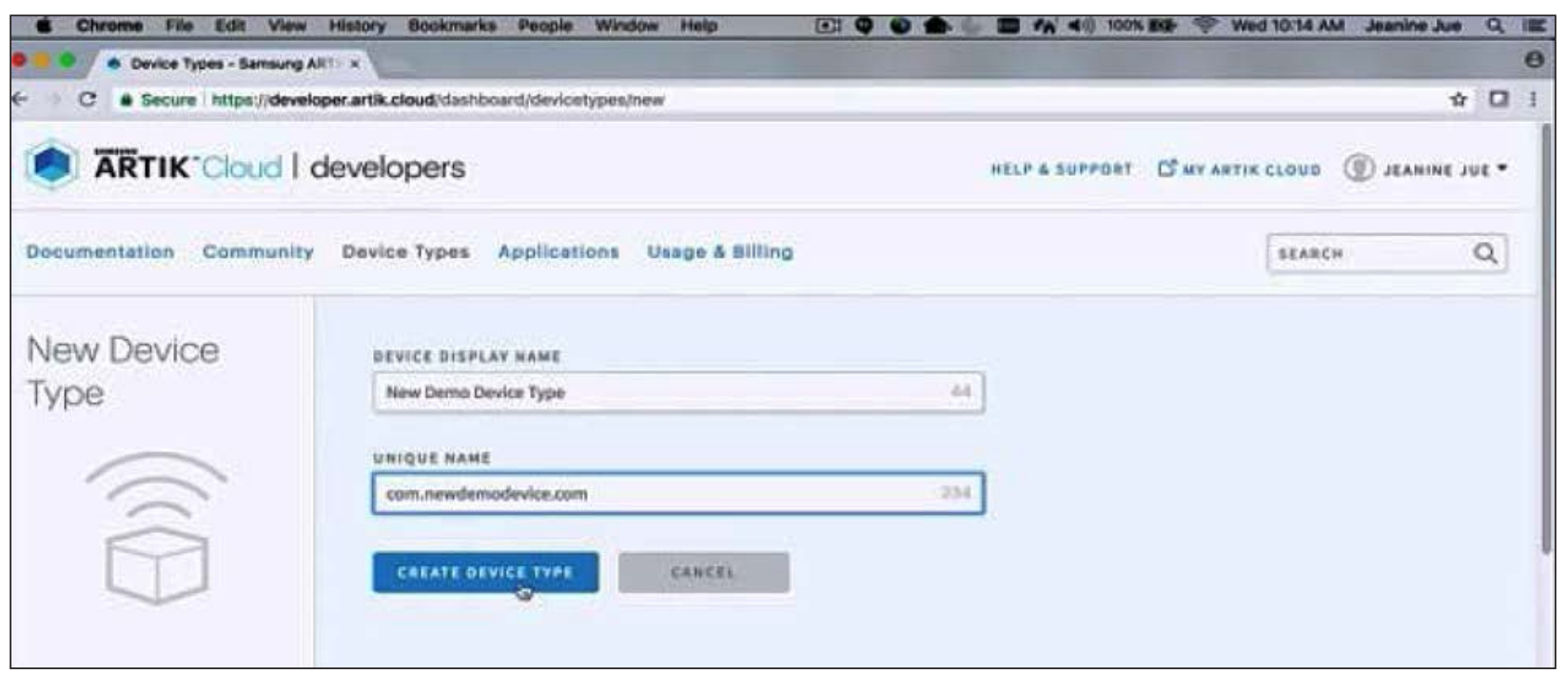

Рис. 2. Перший етап налаштування 
натиснути на кнопку Create device type, адже вона стане активною.

2. Далі відбувається налаштування даних (створення маніфесту, "new manifest") (рис. 3), тобто користувач повідомляє Artik Cloud про дані, які додаток буде посилати, щоб «хмарна» платформа могла витягти дані, що посилаються Android Things-додатком. Наприклад, необхідно вимірювати в приміщенні температуру, вологість та атмосферний тиск. Зазначимо, що вкладки, які відповідають цим параметрам у «хмарному сервісі», слід налаштовувати окремо.

3. Створення віртуального пристрою (рис. 4) чи додавання підключеного пристрою, який надасть інформацію для взаємодії додатка 3 платформою. На цьому етапі завершується конфігурація проєкту Інтернету речей на стороні «хмарної» платформи.

Далі, в проєкті потрібно реалізувати зв'язок із «хмарою» та створеним або підключеним приладом. Зв'язок буде реалізований за допомогою http-з'єднань. Його можна реалізувати, як за допомогою бібліотеки Android НTТР, так і за допомогою призначених для користувача бібліотек, таких як, наприклад, Volley. Ця бібліотека широко використовується в додатках IоT. Також вона спрощує управління http-з'єднанням. Зазначимо, що зв'язок із «хмарою» тоді реалізується в такий спосіб:

1) Створення примірника StringRequest, який представляє http-запит.
2) Налаштування заголовка http-запиту, оскільки додаток повинен посилати параметр заголовка Authorization, як вказано у специфікаціяx Artik, або налаштувати їх відповідно до специфікації інших хмарних платформ.

3) Налаштування «тіла» http-повідомлення, яке відправляється.

4) Додавання запиту в чергу, щоби бібліотека http-запитів змогла обробити його.

У кінці налаштування необхідно переслати дані 3 Android Things-додатка. Щоб зробити це, слід викликати клієнта 3 класу MainActivity.java

(Додаток Android Things - Додаток Јava - Назва пакета Package name). Найпростіший спосіб відправлення даних в Artik Cloud - це використовувати його програмний інтерфейс API щоразц, коли сенсор зчитує нове значення.

Особливості формування запиту до «хмарної» платформи.

Наведемо приклад коду на мові JavaScript (рис. 5), де за результатом його відпрацювання буде отримано повідомлення 3 «хмари» і в браузері буде виведено повідомлення 3 обраного датчика температури.

Рядок «varcall» відповідає за лінк, який формується як результат запиту GET (Get Last Normalized Messages) у профілі Artik Cloud. Параметр авторизації Bearer визначає набір Device Token, який $€$ у вкладці Device info додатка Artik Cloud.

Також у користувача для створеного профілю в «хмарному» середовищі є можливість налаштувати

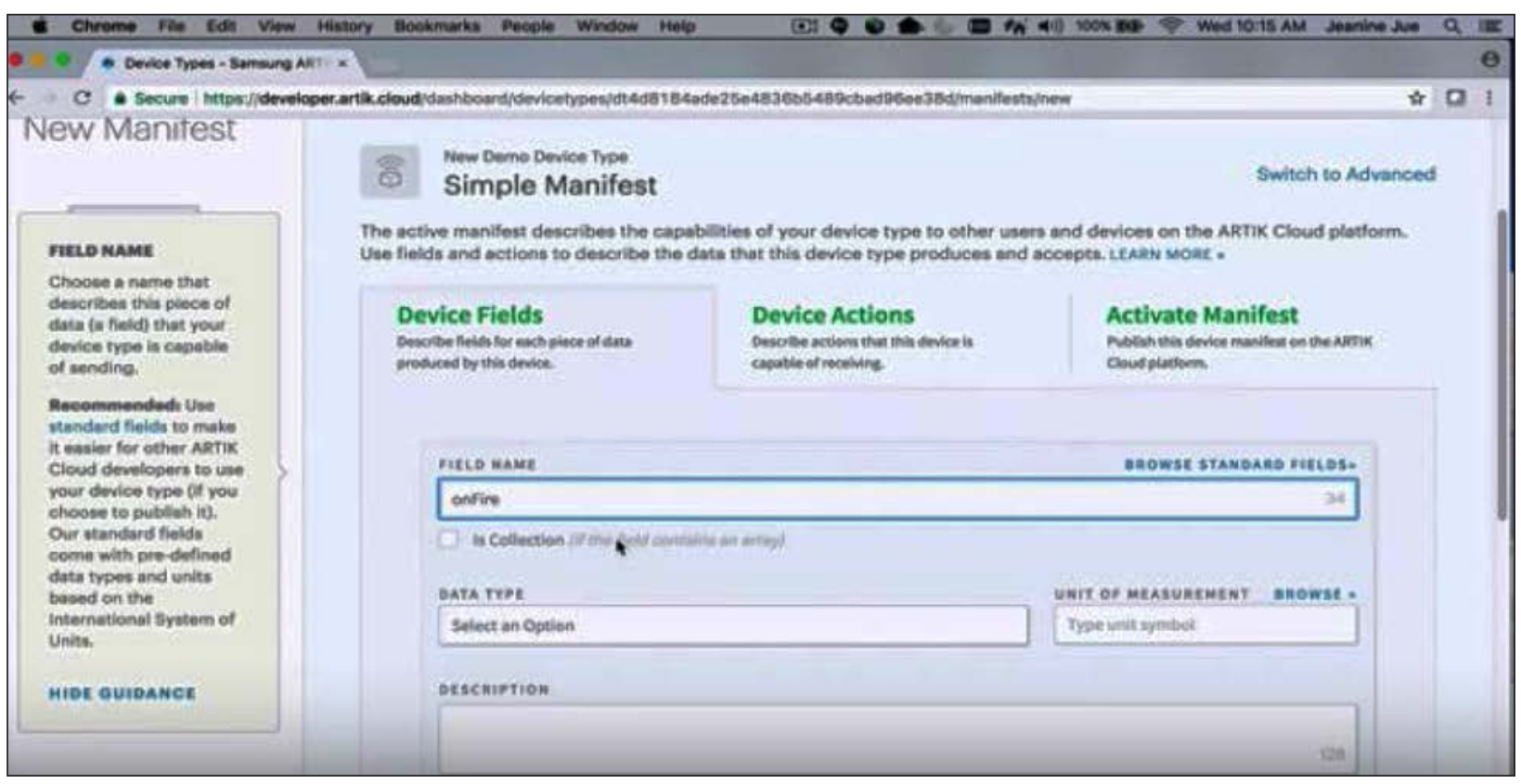

Рис. 3. Другий етап налаштування 
Радіотехніка та телекомунікації
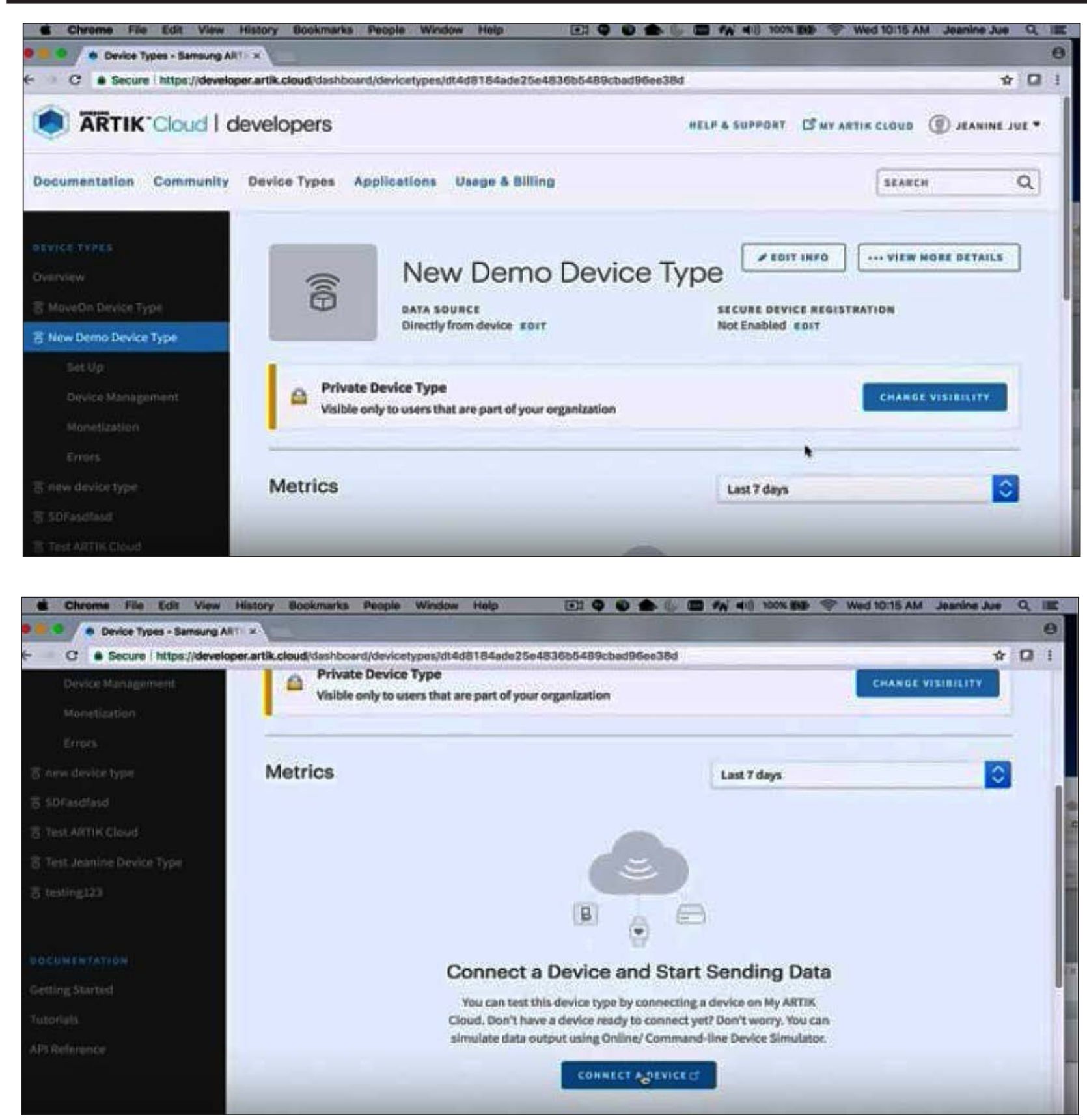

Рис. 4. Третій етап налаштування

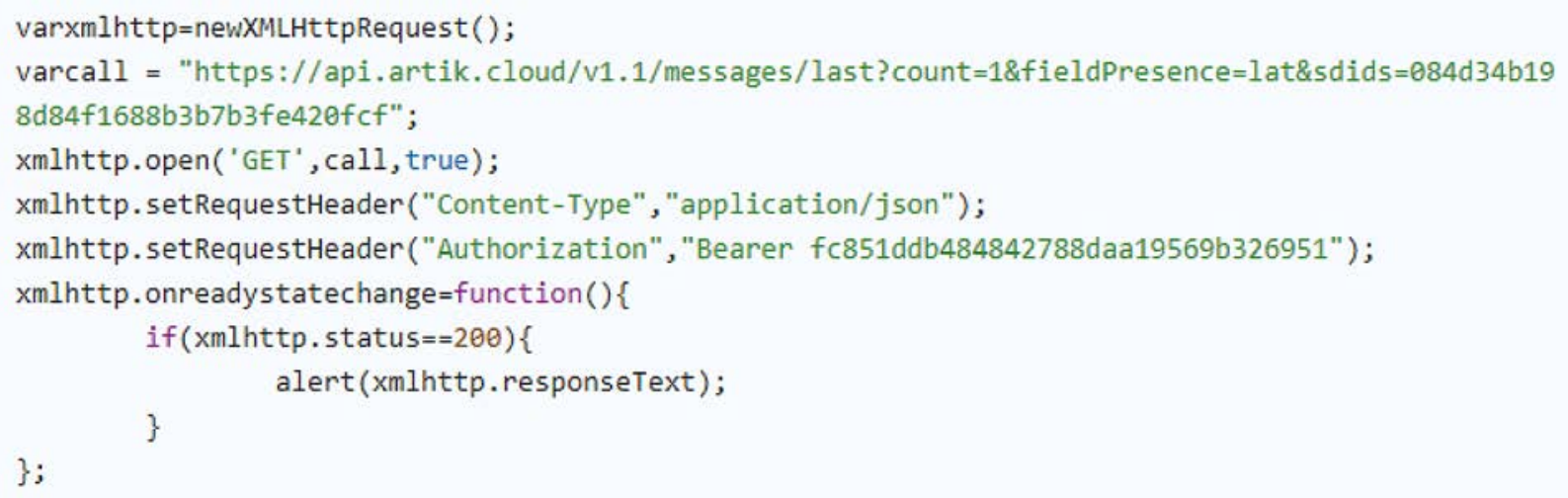


частоту відправлення даних, i, відповідно, фактично можна регулювати смугу пропускання даних, яку необхідно виділити для налаштованого додатка.

За результатом відпрацювання коду з рисунка 5, можна переконатись, що від платформи Artik Cloud приходить відповідь (response), яка повідомляє додаток, що відправлені дані прийнято «хмарою» Artik. Отже, можна переслати досить багато значень параметрів, які вимірюються системою і які потім можна аналізувати в платформі.

Слід зазначити, що є платформи IоT, які надають сервіси інтеграції. Інакше кажучи, вони не сфокусовані на отриманні даних від сенсорів i їхньому зберіганні, їхня мета надання власне сервісів інтеграції з іншими «хмарними» системами. Одна з таких платформ - Temboo [5]. Вона пропонує великий набір сервісів інтеграції, які можуть бути використані, щоб розширити можливості програми Інтернету речей. Теmboo підтримує кілька мов програмування і платформ Інтернету речей, включно з ОС Android.

Для розширення можливостей Інтернету речей платформа Temboo надає можливість зв' язку з численною кількістю програмних додатків. Одним із таких додатків $\epsilon$ Nexmo, на основі якого в користувача системи на основі ІоТ з'являється можливість безпосередньо підключатись до операторів мобільного зв'язку. Особливістю цього додатка слід назвати те, що в основі його є функція перетворення текстового повідомлення SMS в речовий сигнал. Однак тут слід виділити обмеження, яке полягає в тому, що довжина слів у повідомленні не повинна перевищувати межу у 12 текстових знаків. Це пояснюється тим, що у разі перевищення цієї межі речове повідомлення буде зі зникаючими голосовими звуками, що безпосередньо впливає на розбірливість мови.

Висновки. Розглянуто програмні особливості платформи зі створення додатків Android Things і визначено програмні особливості з підключення і налаштування платформи, та проаналізовано режим передавання даних між платформою на основі «хмарних» сервісів і апаратною платою Arduino.

Наведено основні особливості з налаштування однієї з обраних «хмарних» платформ Інтернету речей - Samsung Artik Cloud, і зазначено, що платформа на програмному рівні дає змогу створити профіль для моніторингу даних, які знімаються 3 датчиків системи Інтернету речей.

Знайдено, що для використання «хмарної» платформи в Інтернеті речей досить виконати лише два програмних кроки - конфігурація IoT- проєкту в платформі і додавання пристрою (датчика) в межах підключення до цієї платформи.

Додатково зазначено, що для реалізації сервісів інтеграції з IоT, наприклад для створення голосових повідомлень із набраного тексту, необхідно підключити до ІоТ додаткову спеціальну програмну платформу Temboo. Ця платформа через відповідне програмне забезпечення дає змогу забезпечити підключення до операторів мобільного зв'язку з паралельним конвертуванням текстових повідомлень у голосові.

\section{Список літератури:}

1. Azzola F. Android Things Projects, New York : Packt, 2017. 232 p.

2. Шварц М. Интернет вещей с ЕSP8266. Санкт-Петербург : БХВ-Петербург, 2019. 224 с.

3. Ли П. Архитектура интернета вещей. Москва : ДМК Пресс, 2019. 454 с.

4. Муромцев Д. И., Шматков В. Н. Интернет вещей: введение в программирование на arduino. Санкт-Петербург : 'ИТМО, 2018. 36 с.

5. Бібліотека Temboo. Ресурси сайmy serjmak.com: 4 жовтня 2018. URL: http://serjmak.com/2students/ loTE/temboo-android-sdk-core-2.19.0.jar (дата звернення 15.01.2020).

\section{Borysov H.O., Humen T.F., Trapezon K.O. RESEARCH OF SOFTWARE FEATURES OF ANDROID THINGS UNDER THE CONCEPT OF THE INTERNET OF THINGS}

The software features of the platform for creating Android Things applications are considered. The features of the connection to the platform are identified and the mode of data transmission between the platform based on "cloud" services and the Arduino hardware providing the connection and interaction of sensors within the concept of the Internet of Things is analyzed. Here are some of the key features of setting up one of your favorite Samsung Artik Cloud Cloud Internet Platforms. It is noted that the platform on the hardware (data protection module) and software levels allows the user to create a profile for monitoring data that is taken from the sensors of the Internet of Things. It has been found that to use the cloud-based platform on the Internet of Things, it is sufficient to perform only two program steps - configuring an IoT project on the platform and adding a device (sensor) as part of the connection to that platform. 
A detailed description of how to set up a "cloud" platform for an individual sensor, which measures the temperature of the room, is given. According to this description, an algorithm for providing communication of the array of data from the sensor to the "cloud" platform environment was created. For example, you need to request a code request to send data from an Android application. Additionally it is noted that to implement IoT integration services, for example, to create voice messages from typed text, an additional Temboo platform must be connected to IoT. This platform, through the appropriate software, allows you to additionally connect to mobile operators with the simultaneous conversion of text messages in voice. The peculiarity of this appendix should be noted the restriction, which is that the length of words in the message should not exceed the limit of 12 text characters. This is because when this limit is exceeded, the actual message will have disappearing voice sounds, which directly affect the intelligibility of the language.

Key words: platform, service, sensor, profile, gateway, architecture. 